\title{
The Relationship between Planning of Audit Process and Total Quality Management
}

\author{
Audeh Ahmed Bani-Ahmed ${ }^{1} \&$ Jamal Adel Al-Sharairi ${ }^{1}$ \\ ${ }^{1}$ Department of Accounting, Faculty of Business and Finance Administration/Al Al-Bayt University, Jordan \\ Correspondence: Audeh Ahmed Bani-Ahmed, Department of Accounting, Faculty of Business and Finance \\ Administration/Al Al-Bait University, Jordan. E-mail: audehahahmad@yahoo.com
}

Received: January 26, 2014

Accepted: April 8, $2014 \quad$ Online Published: April 18, 2014

doi:10.5539/ijbm.v9n5p96

URL: http://dx.doi.org/10.5539/ijbm.v9n5p96

\begin{abstract}
The study aimed to identify the impact of the audit process planning on the effectiveness of total quality management, a questionnaire has been designed for this purpose, distributed to (110) external auditors, the recovered questionnaires and appropriate for analysis reached to (77) questionnaires, with a recovery percentage of (70\%), and the questionnaire data was analyzed using the (SPSS), and a number of statistical techniques through descriptive statistics, arithmetic means, standard deviations and percentages. The study hypotheses were tested by multiple regression test. The study found a statistically significant relationship and impact for all independent variables on the effectiveness of total quality management, where the greatest impacts for the variable of preparing audit strategy. The study has recommended the need to increase the interest in the external auditors to plan the audit process, and also increase the interest in documenting the audit process, which will increase the effectiveness of Total Quality Management.
\end{abstract}

Keywords: auditing, total quality management, planning, audit strategy

\section{Introduction}

The audit process planning is a fundamental basis in the exercise of audit process, as the auditor should develop plans and strategies to avoid potential problems, where the plan includes an upgraded help in identifying problems in advance, regardless of their size and complexity, which increase the interest to solve these problems and ensure a neutral and clean opinion about the fairness and credibility of the company's financial statements when being audited.

Based on the above, the external auditor must develop a strategy to ensure conducting all audit activities in the office or the company he works in, which include planning, implementation, monitoring and evaluation, that is a continuous process maintains the quality, it is normal that the company or audit offices are keen on the audit service quality offered by auditing companies, without regard to total quality management and the fact that the overall quality management is a philosophy for an integrated intellectual approach that depends on continuous improvements in product or service in order to achieve the desired goals, in which the most important are satisfying the customer and providing better services.

\subsection{Study Problem}

Planning and strategy are the most important elements of applying total quality management, where achieving the desired goals need to a futuristic vision and specific objectives for a long-term strategy which companies are seeking to achieve and also the participation of an audit team to achieve a strategic plans in order to be unified and coordinated, which allow the planning process to audit and to provide outputs of high quality audit. Hence the problem of the study lies in answering the following questions:

- Is there a statistically significant impact to prepare an audit planning process on Total Quality Management?

- Is there a statistically significant impact to prepare an audit strategy on Total Quality Management?

- Is there a statistically significant impact for documenting the auditing process on Total Quality Management?

\subsection{Study Significance}

The significance of the study representing in showing the importance of the two dimensions of total quality 
management concept and planning concept for external audit process in audit offices, in which audit offices compete with each other in order to present a high-quality reports that enabled them to stay in this area and increase their share in exercising this activity, in addition that audit planning process works to facilitate the performance of auditors in general and audit quality in particular, the study is trying to reveal the impact of audit process planning on the dimensions of the concept of Total Quality Management.

\subsection{Study Objectives}

The study aims to identify the relationship between audit planning and Total Quality Management through the following objectives:

- Identify the impact of preparing for audit process planning on Total Quality Management.

- Identify the impact of preparing audit strategy on Total Quality Management.

- Identify the impact of documenting audit process on Total Quality Management.

\subsection{Study Hypotheses}

H01: There is no statistically significant impact for preparing for audit process planning on Total Quality Management.

H02: There is no statistically significant impact for preparing audit strategy on Total Quality Management.

H03: There is no statistically significant impact for documenting auditing process on Total Quality Management.

\section{Literature Review}

\subsection{Previous Studies}

The purpose of (Ghalib, 2009) study is to identify the extent to which the auditors are committed to the audit process planning under the International Standard no. (300), and to identify the difficulties and obstacles that prevent the application of standards' requirements. The study showed that the auditors in Yemen realize the importance of audit process's planning and their commitment to the requirements of the International Standard no. (300). The study recommended the need for auditors in Yemen to be committed to the requirements of the international standard and to keep contacts with former auditors in compliance with the requirements of professional ethics.

The study of (Al-Amiri \& Al-Mutaz, 2007) aimed to see the impact of audit process planning in the entities that are transforming from traditional system to an electronic commerce system. The study found that $35 \%$ is significantly affected by the expectation of proving the entity's transforming from the traditional system to an electronic commerce system and the moral characteristics have no impact in different answers of the participants in the search.

The study of (Low, 2004) aimed to study the impacts of industry specialization to assess audit's risk assessment and planning procedures, the study showed that the knowledge of the auditor on the audited party has improved in terms of audit's risk assessment and it influenced directly on the nature and quality of planning through knowledge and familiarity with the party being audited, face difficulties and find appropriate solutions.

The study of (Bazazo \& Al-Amayreh, 2010) aimed to diagnose the perceptions of employees in five-star hotels for the importance of applying the principles of Total Quality Management which were represented in customer satisfaction, commitment and support of senior management, continuous improvement and employee involvement and empowerment. The study found a set of results and the most important are: The existence of significant differences in the perception of employees in five-star hotels to the importance of applying the principles of Total Quality Management attributed to some of the variables such as: Experience, education level and lack of statistically significant differences attributed to the level of job and size.

The study of (Saadi, 2009) aimed to identify the impact of applying the comprehensive quality systems on accounting systems in the Jordanian commercial banks, through areas related to focusing on the client, leadership, management, the development of human resources management and electronic clearing. The results showed that the field of electronic clearing ranked first in the application of Total Quality Management and then came the development of human resources management, leadership and management, then focusing on work, the results showed no statistically significant differences for the fields of study depending on variables related to: gender, type of work, level education and years of experience.

The study of (Zickien, 2009) aimed to compare the extent of usingTotal Quality Management between Latvia and the European Union countries, the study found that Latvia is using Total Quality Management, but there was a difference in favor of the European Union and the reason for this is because most of the existing organizations do 
not link quality management with their strategy, in contrary with the European Union countries, and finally the attention to the human element within Total Quality Management was not within the acceptable limit in attention to the human element in organizations, and thus the researcher explained the need for attention because it is the basis of the organizations' advance.

While the study of (Wilkinson \& Others, 2007) aimed to discuss the growing importance of quality management in the United Kingdom, through the outline of the fundamental principles of Total Quality Management and studying their impacts on employee participation. The study concluded that there are contradictions in the elements of Total Quality Management, which represented in the relationship between Total Quality Management and employee participation that has not been fully disclosed by relying on a major program of research on employee participation.

The study of (Wright, Arnold, Wright, \& Sally, 1997) has a significant concern in behavioral research in accounting has been the effect of experience on judgment and decision-making. As widely recognized, there are, however, several dimensions to experience, including general domain experience and task-specific experience. One important dimension that has received limited attention is industry experience. For instance, in an audit context, greater industry experience is expected to lead to greater effectiveness and efficiency as auditors develop a knowledge-base of the unique risks and audit approaches for a particular industry. The purpose of this study is to investigate the impact of industry experience on the generation of hypotheses of likely errors in conducting analytical procedures. Other audit planning tasks are also examined (e.g., risk assessment and extent of testing)

The study of (Fausto \& Galetto, 2010) Quality is a subject 'in fashion': many top managers are giving this matter greater importance now; many gurus are providing their precepts for making quality; many managers attend several seminars on quality looking for 'cooking books'. Actually, quality is a serious and difficult business; it has to become an integral part of management. Too many companies are well behind the desired level of quality management practices. Managers need to learn and put into practice quality ideas. Therefore, some important principles are: relationship between competitiveness and quality, management and quality, management by if ... then...else, scientific approach, intellectual honesty, quality integrity, the three quality identities, the rational manager, TQM2, FAUSTA VIA, etc.

The study of (Bennett \& Kerr, 2010) Despite the widespread application of total quality management TQM in manufacturing and service industries both in the UK and abroad, the majority of these initiatives fail in the first few years The evidence that TQM initiatives quickly lose momentum and flounder is widespread and abundant. This study critically examines one manufacturing company's approach to TQM in practice, and explores the value of applying systems thinking to the implementation of such an initiative. The particular systems approach used was Check land's soft systems methodology SSM, supported by the ideas of systems dynamics. This analysis highlighted the strengths and weaknesses of the company's current total quality program and resulted in several recommendations for change. SSM proved to be an extremely valuable tool for investigating such implementation difficulties. We believe that this study demonstrates both the pressing need for a systems approach to the implementation of TQM and the potential of SSM as a specific systems approach for this application.

\subsection{Theoretical Literature}

\subsubsection{Audit Process Planning Requirements}

The two researchers believe that a regular audit process contains many important and serial steps, and must be completed in a certain time, far from random and capricious nature, as time is precious, we must develop a strategic prior plan, containing comprehensiveness of objectives, nature, scope and timing of a clean and neutral opinion, so that it can be implemented easily and smoothly and achieve audit objectives. The researchers also believe that when preparing for planning audit process, we should take into account: The size of the audited company, regulatory laws and the financial regulations of the audited company, previous solutions to the problems in auditing, discussing audit plan and its procedures with the audit team and the internal audit unit in the company and determine important decisions concerning the relative importance.

Prepare for Audit Process Plan (Initial Activities): International Standard no. (300) in paragraphs (5to10 and 13) related to the initial activities and additional considerations:

Article (5): Each partner in the process and other key members of the team shall involve in auditing planning process, which includes planning and participating in the discussions between team process members.

Article (6): The auditor shall conduct preliminary activities at the beginning of the audit process that are: Continuing the relationship with the client and the specific audit process, assess the compliance with ethical and independence requirements to achieve an understanding of the conditions of the process. 
Article (13): The auditor shall perform the following activities before starting the initial audit process:

A- Performing the procedures stipulated in the International Auditing Standard no. (220) regarding the acceptance of the client relationship and the limited audit process.

B- Contacting with the previous auditor, where there is a change in auditors, in compliance with relevant ethical requirements.

Preparing Audit Strategy: As stipulated in articles (7-11), (A8-A10), (A12-A13) of the stipulation of the International Standard no. (300) and for the preparation of the overall audit strategy and audit plan:

Article (7): The auditor shall develop a comprehensive audit strategy that describes the scope, timing and direction of the audit and provide guidance in the development of the audit plan.

Article (8): The auditor in case of putting a comprehensive audit plan shall consider the following:

A- Determining the characteristics of the process by showing its scope.

B- Verifying the objectives of preparing planning process reports related to the audit timing and the nature of the required communications.

C- Studying the factors that are considered in accordance with professional estimating are important in directing the efforts of a team process.

D- Determining the primary activities outcomes of the process, when possible, to know if gained knowledge in other operations is performed for the entity by the operational partner is considered convenient.

E- Verifying the nature, timing and scope of resources needed to perform the operation.

Article (9): The auditor shall develop a plan that includes a statement for the following:

A- The nature, timing and scope of planned risk assessment procedures.

B- The nature, timing and scope of planned risk assessment procedures at the proof level.

C- Other planned audit procedures to be implemented, so that the process can comply with international auditing standards.

Article (10): The auditor shall update and change the overall audit strategy and plan, so that it will be mandatory in the context of auditing.

Article (11): The auditor shall plan for the nature, timing and scope of the guidance and supervision of the operation team members and review their work.

Article (A8): The process of developing a comprehensive audit strategy helps the auditor to identify the following issues, taking into account the auditor's procedures for risk assessment:

* Resources that will be used for specific aspects of auditing, such as hiring team members with appropriate expertise in the areas of high risk or the involvement of experts on complex issues.

* The amount of resources that will be allocated to specific aspects of the audit, such as the number of team members involved in inventory control at important sites and the extent to review other auditors' work in case of group auditing or budget auditing in hours which will be allocated to high-risk areas.

* When these resources will be used, either in the interim audit stage or at Cut-off Dates.

* How to manage, direct and supervise these resources, such as the time needed to convene group meetings to get acquainted with the information or extracted it and how do we expect the partner and director of the operation to revise (for example, on-site or off-site), and whether the quality control on the process will be revised.

Article (A9): Appendix lists examples of considerations in the development of a comprehensive audit strategy.

Paragraph (10A): Once the overall audit strategy is set, it becomes possible to design audit plan for dealing with various issues that have been identified in the overall audit strategy, taking into account the need to achieve the audit objectives through the efficient use of the auditor's resources. The development of the overall audit strategy and audit plan are not necessarily two separate processes, but closely linked in that changes in one may result in changes in the other.

Paragraph (12A): Audit plan will be more detailed from the overall audit strategy as it includes the nature, timing and scope of audit procedures to be performed by members of the team process.

Paragraph (13A): As a result of unexpected events or changes in circumstances or audit evidences that are obtained from the results of audit procedures, the auditor may require to amend the audit strategy and 
comprehensive audit plan, adjusting the nature, timing and extent of resulting and planned additional audit procedures, on the basis of the study of the modified risks.

This can be the case when the information reaches to the attention of the auditor, which is different from the available information when the auditor plans for auditing procedures, for example, the audit evidence obtained through the performance of key actions could contradict with the audit evidence obtained from tests control systems.

Audit Process Documentation: As stipulated in articles: (12), (A16, A17 and A18) of the stipulation of the International Standard no. (300) related to the documentation of the audit process:

Article (12): The auditor shall document the overall audit strategy, audit plan and any significant changes occur during the process of auditing on the overall audit strategy or audit plan and the reasons for these changes.

Article (A16): The auditor shall register the documentation of the main decisions of overall audit strategy that are essential for audit planning properly and inform the important things to the team process, for example, auditor can summarize the overall audit strategy by a memorandum containing the main decisions relating to scope, timing and overall performance to the audit process.

Article (A17): The auditor shall register the documentation of the statement by showing the nature of the audit plan, timing and the scope of risk assessment procedures and further audit procedures at the level of proof in response to the assessed risks, a proper planning for audit procedures that can be reviewed and approved before the performance should also be registered. The auditor can use a unified audit programs or check lists for the completion of the audit, which can be designed as necessary to reflect the specific circumstances of the operation.

Article (A18): The important changes' record that occur to the audit strategy and comprehensive audit plan and changes resulting from the nature of the audit procedures, timing and its planned scope, explain why a significant changes, the overall strategy and audit plan that were adopted in the final audit, also reflects an appropriate response to changes important that occur during the audit.

Total Quality Management: Total Quality Management means all activities undertaken by officials of the organization to conduct its work, it includes planning, implementation, monitoring and evaluation, it is a process that continues to maintain quality (Olimat, 2004), the organization may produce a high-quality product without applying the Total Quality Management, because the organization has focused on quality element so that the product can conform to the specifications and standards that must be on the basis of production of the product (Al-Samurai, 2007).

Also Total Quality Management defined as a philosophy of integrated intellectual approach depends on the satisfaction of consumers as the most important goals for consumers through cooperation between management and workers through solidarity responsibility for continuous improvements to all activities and at the level of the organization as a whole (Alwan, 2005).

The areas that can be summarized by Total Quality Management are many, but the researchers chose three areas that are suitable for the study population, and therefore, what are taken by the researchers are considered in the area of total quality management.

\subsubsection{Supreme Administrative Leadership in the Organization}

The decisions that are related to total quality management are one of the strategic decisions that must be considered by senior management of the organization, so the senior management shall emphasize on the support of workers and promote a culture of quality among them and the work which should be done to the fullest by building a comprehensive vision and a clear strategy in the framework of the organization to achieve its objectives (Al-Azzawi, 2005).

Total Quality Management requires from leaders the obligation of adopting its concept, elements and absorbed it properly and follow the sound foundation in the application in business organizations in general and universities in particular, especially that Jordanian official universities have a message which differs from other organizations, and also the researchers finds that Total Quality Management must be applied in all departments and universities' centers, especially the financial department and internal control department.

\subsubsection{Attention to Human Resources}

Human Resources Management aims at forming and developing human resource in the organization to become more skilled and more able to take responsibility (Burk, 1997).

Human resources management must be integrated with the organization's operations and strategic objectives, so 
organizations must take care of the human element and his activity, by providing the appropriate atmosphere for him and that the organization -when following a quality strategy-will help employees to accept the change as it leads to gain a competitive advantage for the organization and quality strategies of human resources, which include training, learning and involve them in decision-making and enable them to accomplish works perfectly with minimal effort (Noori \& Radford 1995).

(Al-Khalaf, 2005) classified human resources management into two categories: The technical element, which includes the design, production and tools to control them and the human element that refers to encourage, urge, train and motivate employees for commitment and actively participation in continuous improvement operations and to focus on the human element and interest in general.

\subsection{Strategic Planning}

Strategy is one of the most important elements in the application of total quality management, since the Jordanian public universities work to develop a five-year and annual plans in order to improve and develop the message for which the public universities in Jordan were established.

The application of total quality management process requires a specific vision for the future and a long-term strategic goal that the organizations seek to achieve, and also requires the participation of all employees in achieving a strategic plans to be unified and coordinated in a way that enables the evaluation process of what has been accomplished (Al-Khalaf, 2005).

The two researchers believe that strategic planning in light of Total Quality Management in audit offices in general are: Quality planning, addressing distortions and imbalances tell it reaches to scratch, notifying all of the customers (companies being audited) with safety, notify the audit team and make way for workers to participate in all audit activities, including participation in the decision-making.

\section{Population's Study and Its Sample}

The study population consists of Jordanian audit offices that are (53) according to the Jordanians Chartered Accountants Association statistics, the questionnaire distributed to practitioners auditors in Amman province, with (110) questionnaires, (77) of which were suitable for analysis and 70\% percentage were retrieved.

\section{Description of Study Sample Characteristics}

Table 1. Characteristics of the study sample

\begin{tabular}{llll}
\hline Item & Variable & Number & Percentage\% \\
\hline Qualification & -Bachelor & 50 & $65 \%$ \\
& -Master & 20 & $26 \%$ \\
& -Doctorate & 7 & $9 \%$ \\
\hline Specialization & -Accounting & 60 & $78 \%$ \\
& -Business Management & 7 & $9 \%$ \\
& -Finance and Banking & 7 & $9 \%$ \\
\hline Experience in auditing & -Economy & 3 & $4 \%$ \\
& -Less than 5 years & 30 & $39 \%$ \\
& -From 5-10 years & 30 & $39 \%$ \\
& -From 10 -15 years & 7 & $9 \%$ \\
& -From 15 years and more & 10 & $13 \%$ \\
\hline
\end{tabular}

We note from Table 1 that the majority of the study sample hold bachelor degrees with a percentage of $65 \%$, followed by Masters by $26 \%$, then doctorate by $9 \%$ and there is no certificate less than bachelor; implying the existence of qualification which enable the sample to answer the questions of the questionnaire better. Regarding specialization item, we note that the majority of the study sample are specialized in accounting with a percentage of $78 \%$, followed by business management and finance and banking by $9 \%$, and finally the economy by $4 \%$ and this shows that those who practiced auditing, mostly majoring in accounting degree, who are more familiar than others in the areas of audit and developments. Regarding experience, we note that the majority of the study sample's experiences were less than (5 years) (5-10 years) with the same percentage of 39\%, followed by increase in their experience (15 years) increased by $13 \%$ and, finally, those who experience (10-15) at a percentage of $9 \%$. Based on the above, we find that the majority of the study sample has sufficient experience to answer the 
questionnaire paragraphs accurately.

\subsection{Study Variables}

Based on the problem of the study and its hypotheses, the independent variables are as follows: Prepare for audit process planning, preparation of audit strategy, documenting the audit process, while the dependent variable is total quality management.

\subsection{Study Tool: Its Description, Persistence and Sincerity}

A tool was developed to achieve the purposes of the study by reviewing the theoretical literature on the requirements of audit planning process, where the most important audit requirements planning were calculated as stipulated in the International Standard no. (300) to study the impact on total quality management, the tool of the study included two parts:

Part One: Related to demographic factors of Jordanians Chartered Accountants (external auditors), as follows: Qualification, experience in the field of auditing and specialization.

Part Two: Was allocated to measure the impact of the requirements of audit planning process on total quality management, Five Likert scale was adopted in the development of study tool on calculated weights paragraphs as follows: for (Strongly Agree) ( 5 degrees) were given, for (Agree) (4 degrees) were given, for (Moderately Agree) (3 degrees) were given, and for (Disagree) (2 degrees) were given, and for (Strongly Disagree) (one degree) were given. To interpret the data, it will be dealt with as follows: (1-2.49) means a low degree, and (2.50-3.49) means medium degree, and (3.5-5) means a high degree. The questionnaire was distributed with its 50 paragraphs and four fields to include all the independent variables and the dependent variable.

\subsection{Statistical Methods}

For the purposes of analyzing the study data, the following statistical methods were used:

Descriptive Analysis: This analysis was based on arithmetic mean, standard deviation, percentages and the multiple regression analysis to measure the impact of the independent variables (Audit Process Planning) on the dependent variable (Total Quality Management) and also to study and test tool and its reliability in testing hypotheses, and to achieve the objectives of the study, internal consistency Cronbach's alpha measure has been used to measure the stability of the answers of the study sample about the questions of the questionnaire. (Sekaran, 2003) explains internal consistency coefficient between the answers that the acceptable value statistically for this measure is $60 \%$ or more, the results of this factor have shown that the stability in the areas of the tool was very high; this confirms the reliability of the questionnaire to test hypotheses, as illustrated in the table below.

Table 2. Cronbach's alpha coefficients persistence for fields of study

\begin{tabular}{lll}
\hline Field & Questions' Number & Alpha Coefficient \\
\hline Prepare for Audit Process Planning (Initial & 10 & 0.86 \\
Activities) & 20 & 0.81 \\
Preparing Audit Strategy & 10 & 0.92 \\
Documenting Audit Process & 10 & 0.79 \\
Total Quality Management (The Dependent & 50 & 0.88 \\
Variable) & 5 \\
The tool as a whole & & \\
\hline
\end{tabular}

The meaning of tool sincerity is the process of making sure that the statements contained in the study tool that can lead to the collection of data accurately (Sekaran, 2003). Tool of the study was presented on a number of specialists in the field of accounting in Jordanian universities to see which questionnaire's paragraphs are linguistically appropriate and extent of their affiliation to the dimension which they placed within, arbitrators' observations and opinions were taken into account and some of the paragraphs were reformulated in the light of these observations.

Variance Inflation Factor was used to make sure that there is a link-quality between the Multi collinearity variables. 
Table 3. Strength of study model test

\begin{tabular}{ll}
\hline Model & VIF \\
\hline Prepare for Audit Process Planning (Initial Activities) & 3.650 \\
Preparing Audit Strategy & 2.230 \\
Documenting Audit Process & 3.002 \\
\hline
\end{tabular}

Since the value of (VIF) is less than (4) for all the variables, it means that there is no overlap between the independent variables, reflecting the strength of the study model.

\subsection{Data Analysis of the Study Fields}

In order to describe the impact of audit planning requirements on Total Quality Management, the two researchers extract arithmetic means, standard deviations to the study sample estimates on questionnaire's paragraphs and the following table illustrate this.

Table 4. The first field: prepare for audit process planning (initial activities) ( $\mathrm{n}=77)$

\begin{tabular}{|c|c|c|c|c|}
\hline Number & Prepare for Audit Process Planning (Initial Activities) & $\begin{array}{l}\text { Arithmetic } \\
\text { Mean }\end{array}$ & $\begin{array}{l}\text { Standard } \\
\text { Deviation }\end{array}$ & Ranking \\
\hline 1 & $\begin{array}{l}\text { The size of the audited company is taking into account when } \\
\text { preparing for planning. }\end{array}$ & 3.92 & 0.68 & 5 \\
\hline 2 & $\begin{array}{l}\text { Regulatory laws and financial regulations of the audited company are } \\
\text { taken into account when preparing for planning. }\end{array}$ & 4.25 & 0.57 & 1 \\
\hline 3 & $\begin{array}{l}\text { Previous solutions to problems are taken into account when preparing } \\
\text { for planning. }\end{array}$ & 4.04 & 0.86 & 3 \\
\hline 4 & Audit plan and its procedures are discussed with the audit team. & 4.06 & 0.69 & 2 \\
\hline 5 & $\begin{array}{l}\text { The audit plan and its procedures are discussed with the Internal Audit } \\
\text { Unit. }\end{array}$ & 3.78 & 0.75 & 8 \\
\hline 6 & $\begin{array}{l}\text { The auditor conducts initial activities at the beginning of the audit } \\
\text { process that are: continuing the relationship with the client and the } \\
\text { specific audit process, as required by the International Auditing } \\
\text { Standard no. } 220 \text {. }\end{array}$ & 3.64 & 0.87 & 9 \\
\hline 7 & $\begin{array}{l}\text { The auditor evaluates the compliance with the independence and } \\
\text { ethical requirements to achieve an understanding for the process } \\
\text { conditions. }\end{array}$ & 3.86 & 0.62 & 6 \\
\hline 8 & $\begin{array}{l}\text { The current auditor will contact with the previous auditor before } \\
\text { starting the audit process. }\end{array}$ & 3.79 & 0.54 & 7 \\
\hline 9 & $\begin{array}{l}\text { Decisions related to the relative importance are determined when } \\
\text { preparing for planning. }\end{array}$ & 3.99 & 0.52 & 4 \\
\hline 10 & $\begin{array}{l}\text { Individuals' requirements and the audit team should be specified } \\
\text { when preparing for planning. }\end{array}$ & 4.06 & 0.44 & 2 \\
\hline \multicolumn{2}{|c|}{ Total field /Prepare for Audit Process Planning (Initial Activities). } & 3.92 & 0.49 & -------- \\
\hline
\end{tabular}

Table 4 shows that measuring degree of prepare for audit process planning (initial activities) in all paragraphs is high, arithmetic mean has ranged between (4.25-3.64), paragraph (2) has occupied the first rank, with a mean of (4.25), which is the highest means, paragraphs (4) and (10) have occupied the second rank with arithmetic mean of (4.06), paragraph (6) came at last rank, with arithmetic mean of (3.64), the arithmetic mean of the total area/prepare for audit process planning (initial activities) reached (3.94). 
Table 5. The second field: preparing audit strategy $(n=77)$

\begin{tabular}{|c|c|c|c|c|}
\hline Number & Preparing Audit Strategy & $\begin{array}{c}\text { Arithmetic } \\
\text { Mean }\end{array}$ & $\begin{array}{l}\text { Standard } \\
\text { Deviation }\end{array}$ & Ranking \\
\hline 11 & $\begin{array}{l}\text { The auditor develops a comprehensive audit strategy which } \\
\text { describes the scope, timing and direction of the audit and provides } \\
\text { guidance when developing an audit plan. }\end{array}$ & 3.79 & 0.41 & 10 \\
\hline 12 & $\begin{array}{l}\text { The auditor determines the characteristics of the process that show } \\
\text { its scope when developing a comprehensive audit plan. }\end{array}$ & 3.60 & 0.62 & 13 \\
\hline 13 & $\begin{array}{l}\text { The auditor verifies the objectives of planning process reports for } \\
\text { the timing of the audit and the nature of the required } \\
\text { communications when developing a comprehensive audit plan. }\end{array}$ & 3.92 & 0.44 & 7 \\
\hline 14 & $\begin{array}{l}\text { The auditor studies the factors that are considered in accordance } \\
\text { with professional judgment important in directing the efforts of a } \\
\text { team process when developing a comprehensive audit plan. }\end{array}$ & 4.13 & 0.62 & 3 \\
\hline 15 & $\begin{array}{l}\text { The auditor determines the initial results of process activities, } \\
\text { wherever possible, and whether the knowledge is gained in other } \\
\text { operations that are performed for the entity by a partner of the } \\
\text { operation, which is considered convenient when developing a } \\
\text { comprehensive audit plan. }\end{array}$ & 3.86 & 0,50 & 8 \\
\hline 16 & $\begin{array}{l}\text { The auditor verifies the nature, timing and scope of the resources } \\
\text { needed to perform the operation when developing a comprehensive } \\
\text { audit plan. }\end{array}$ & 3.99 & 0.52 & 5 \\
\hline 17 & $\begin{array}{l}\text { The auditor develops a plan that includes a statement of the nature, } \\
\text { timing and scope of the planned risk assessment procedures. }\end{array}$ & 4.12 & 0.62 & 4 \\
\hline 18 & $\begin{array}{l}\text { The auditor develops a plan that includes a statement of the nature, } \\
\text { timing and scope of risk assessment procedures planned at the proof } \\
\text { level. }\end{array}$ & 3.79 & 0.66 & 10 \\
\hline 19 & $\begin{array}{l}\text { The auditor develops a plan that includes a statement of other } \\
\text { planned audit procedures to be implemented, so that the process can } \\
\text { complies with the International Standards of Auditing. }\end{array}$ & 4.19 & 0.55 & 1 \\
\hline 20 & $\begin{array}{l}\text { The auditor updates and changes the overall audit strategy and audit } \\
\text { plan, so the context of the audit will be obligatory. }\end{array}$ & 3.86 & 0.62 & 8 \\
\hline 21 & $\begin{array}{l}\text { The auditor prepares plans concerning the nature, timing and scope } \\
\text { of the guidance and supervision of the operation team members and } \\
\text { reviews their work. }\end{array}$ & 3.94 & 0.58 & 6 \\
\hline 22 & $\begin{array}{l}\text { The process of developing a comprehensive audit strategy helps the } \\
\text { auditor to identify the resources that will be used for specific } \\
\text { aspects of auditing, such as hiring team members with appropriate } \\
\text { expertise in the fields of high risk or involve experts in complex } \\
\text { issues. }\end{array}$ & 4.14 & 0.63 & 2 \\
\hline 23 & $\begin{array}{l}\text { The process of developing a comprehensive audit strategy helps the } \\
\text { auditor to determine the amount of resources that will be devoted to } \\
\text { specific aspects of auditing, such as the number of team members } \\
\text { involved to monitor the inventory in important positions and the } \\
\text { extent to review the work of other auditors in case of groups } \\
\text { auditing or balance the audit process in hours to be allocated to high } \\
\text { risk areas. }\end{array}$ & 3.99 & 0.52 & 5 \\
\hline 24 & $\begin{array}{l}\text { The process of developing a comprehensive audit strategy helps the } \\
\text { auditor to determine when these resources will be used, either in the } \\
\text { interim audit stage or at Cut-off Dates. }\end{array}$ & 4.19 & 0.40 & 1 \\
\hline 25 & $\begin{array}{l}\text { The process of developing a comprehensive audit strategy helps the } \\
\text { auditor to determine how to manage, direct and supervise these } \\
\text { resources, such as: time, which is expected to be convenience for } \\
\text { team meetings to view the information and how it is expected for } \\
\text { the partner and director to revise them (for example, on-site or } \\
\text { off-site), and whether the quality control on the process will be }\end{array}$ & 3.73 & 0.57 & 12 \\
\hline
\end{tabular}


completed.

It is possible to develop a comprehensive audit plan that addresses the various things that have been identified in the overall audit strategy, taking into account the need to achieve the audit objectives through the efficient use of auditor's resources.

The development of the overall audit strategy and audit plan are not necessarily two separate processes, but closely linked in that changes in one may result changes in the other.

Audit plan are more detailed than the overall audit strategy in that it includes the nature, timing and scope of audit procedures to be performed by members of the operation team.

The auditor needs to modify the overall audit strategy and audit plan as a result of unexpected events or changes in circumstances or audit evidence that are obtained from the results of audit procedures.

The auditor modifies the nature, timing and extent of audit procedures resulted and planned from it on the basis of the modified study of the assessed risks.

\begin{tabular}{|c|c|}
\hline 3.80 & 0.54 \\
\hline 3.74 & 0.57 \\
\hline 3.53 & 0.73 \\
\hline 3.52 & 0.88 \\
\hline 3.53 & 0.72 \\
\hline 87 & 0.28 \\
\hline
\end{tabular}

Table 5 shows that the degree measure of preparing audit strategy in all paragraphs are high, the arithmetic mean has ranged between (4.19-3.52), the paragraphs (19) and (24) have occupied the first rank, with a mean of (4.19), which is the highest mean, paragraph (22) has occupied the second rank, with a mean of (4.24), and paragraph (29) came last, with a mean of (3.52), the arithmetic mean of the total area / Preparing Audit Strategy has reached (3.87).

Table 6. The third field: documenting audit process $(\mathrm{n}=77)$

\begin{tabular}{|c|c|c|c|c|}
\hline Number & Documenting Audit Process & $\begin{array}{c}\text { Arithmetic } \\
\text { Mean }\end{array}$ & $\begin{array}{l}\text { Standard } \\
\text { Deviation }\end{array}$ & Ranking \\
\hline 31 & The auditor documents the overall audit strategy. & 3.01 & 0.63 & 1 \\
\hline 32 & The auditor documents the audit plan. & 2.81 & 0.75 & 2 \\
\hline 33 & $\begin{array}{l}\text { The auditor documents any significant changes arise during the audit } \\
\text { process on the overall audit strategy or audit plan. }\end{array}$ & 2.75 & 0.86 & 3 \\
\hline 34 & $\begin{array}{l}\text { The auditor documents the explanation of the reasons for these } \\
\text { changes arise during the audit process on the overall audit strategy or } \\
\text { audit plan. }\end{array}$ & 2.60 & 0.72 & 6 \\
\hline 35 & $\begin{array}{l}\text { The auditor records the documenting for the overall audit strategy } \\
\text { main decisions that are necessary to properly audit planning and } \\
\text { reporting important things to the team process. }\end{array}$ & 2.81 & 0.76 & 2 \\
\hline 36 & $\begin{array}{l}\text { The auditor summarizes the overall audit strategy in a form of a } \\
\text { memorandum contains the main decisions relating to the scope, } \\
\text { timing and overall performance of the audit process. }\end{array}$ & 2.74 & 0.87 & 4 \\
\hline 37 & $\begin{array}{l}\text { The auditor documents the audit plan on a statement related to the } \\
\text { nature, timing and scope of risk assessment procedures and further } \\
\text { audit procedures at the level of proof in response to the assessed risk. }\end{array}$ & 2.68 & 0.71 & 5 \\
\hline 38 & $\begin{array}{l}\text { Auditor records proper planning of the audit procedures that can be } \\
\text { reviewed and approved before the performance. }\end{array}$ & 2.48 & 0.62 & 8 \\
\hline 39 & $\begin{array}{l}\text { The auditor documents the use of standard audit programs or } \\
\text { checklists for the completion of audit process, and to be designed } \\
\text { appropriately to reflect the specific circumstances of the process. }\end{array}$ & 2.74 & 0.87 & 4 \\
\hline 40 & $\begin{array}{l}\text { The auditor documents the solutions to complex issues affecting the } \\
\text { client. }\end{array}$ & 2.55 & 0.97 & 7 \\
\hline \multicolumn{2}{|c|}{ Total Area/ Documenting Audit Process } & 2.72 & 0.59 & \\
\hline
\end{tabular}


Table 6 shows the degree measure of documenting audit process in all paragraphs which were medium except paragraph (38), which ranked last, with a mean of (3.48), the arithmetic mean ranged between (3.01-2.48), paragraph (31) ranked first, with a mean of (3.01), which is the highest mean, paragraphs (32) and (35) ranked second, with a mean of (2.81), and the arithmetic mean of the total area/ Documenting Audit Process has reached (2.72).

Table 7. Fourth field: total quality management $(n=77)$

\begin{tabular}{|c|c|c|c|c|}
\hline Number & Total Quality Management & $\begin{array}{l}\text { Arithmetic } \\
\text { Mean }\end{array}$ & $\begin{array}{l}\text { Standard } \\
\text { Deviation }\end{array}$ & Ranking \\
\hline 1 & $\begin{array}{l}\text { Senior management in the audit offices adopts quality management's } \\
\text { concept and its elements. }\end{array}$ & 4.00 & 0.65 & 7 \\
\hline 2 & $\begin{array}{l}\text { Correct principles in applying Total Quality Management in audit } \\
\text { office are followed. }\end{array}$ & 4.19 & 0.55 & 4 \\
\hline 3 & $\begin{array}{l}\text { The culture of total quality is spread by the senior management on the } \\
\text { audit team. }\end{array}$ & 4.38 & 0.61 & 1 \\
\hline 4 & $\begin{array}{l}\text { Senior management in your office supports and follows-up the } \\
\text { completion of total quality requirements. }\end{array}$ & 4.06 & 0.45 & 6 \\
\hline 5 & $\begin{array}{l}\text { Senior management leadership is working to generate self-leadership } \\
\text { in your office. }\end{array}$ & 4.06 & 0.44 & 6 \\
\hline 6 & $\begin{array}{l}\text { A comprehensive vision is being built by the leadership for the work } \\
\text { to be accomplished inside and outside the office. }\end{array}$ & 4.35 & 0.48 & 2 \\
\hline 7 & $\begin{array}{l}\text { Your office is constantly seeking to evaluate the performance of the } \\
\text { team on a regular basis and granting additional incentives. }\end{array}$ & 4.20 & 0.40 & 3 \\
\hline 8 & $\begin{array}{l}\text { Your office is always sought to urge the team to correct errors through } \\
\text { periodic meetings with them and use quality standards (as an average } \\
\text { error) as a basis for giving incentives for auditors. }\end{array}$ & 4.19 & 0.55 & 4 \\
\hline 9 & There are plans within the strategic plans to improve performance. & 4.13 & 0.50 & 5 \\
\hline 10 & $\begin{array}{l}\text { Within the strategic plans, there are plans to acknowledge and assess } \\
\text { the achievement, set objectives and the implementation mechanism. }\end{array}$ & 3.99 & 0.52 & 8 \\
\hline \multicolumn{2}{|c|}{ Total Field /Total Quality Management } & 4.17 & 0.30 & \\
\hline
\end{tabular}

Table 7 shows that the degree measure of the effectiveness of time management in all paragraphs are high, the arithmetic mean has ranged between (4.38-3.99), paragraph (3) ranked first, with a mean of (4.38), which is the highest mean, paragraph (6) ranked second, with a mean of (4.35), paragraph (10) ranked last, with a mean of (3.99), the arithmetic mean of the total area / Total Quality Management has reached (4.17).

Table 8. The results of multiple linear regression for the impact of audit planning requirements on total quality management $(n=77)$

\begin{tabular}{|c|c|c|c|c|c|c|c|c|c|}
\hline $\begin{array}{l}\text { Independent } \\
\text { Variables }\end{array}$ & $\begin{array}{l}\text { Calculated } \\
\text { (T) Value }\end{array}$ & $\begin{array}{l}\text { Statistical } \\
\text { Significance } \\
\text { (a) }\end{array}$ & $\begin{array}{l}\text { The } \\
\text { Correlation } \\
\text { Coefficient(r) }\end{array}$ & $\begin{array}{l}\text { Coefficient } \\
\text { Determination } \\
\left(\mathbf{R}^{2}\right)\end{array}$ & $\begin{array}{l}\text { Regression } \\
\text { coefficient } \beta\end{array}$ & $\begin{array}{l}\text { Standard } \\
\text { Deviation } \\
\text { coefficient } \\
\text { (Beta) }\end{array}$ & $\begin{array}{l}\text { Calculated } \\
\text { (F) Value }\end{array}$ & $\begin{array}{l}\text { Statistical } \\
\text { Significance }\end{array}$ & $\begin{array}{l}\text { Null } \\
\text { hypothesis } \\
\text { test result }\end{array}$ \\
\hline $\begin{array}{l}\text { Prepare for Audit } \\
\text { Process Planning } \\
\text { (Initial Activities) }\end{array}$ & 3.175 & 0.002 & 0.737 & 0.54 & 0.205 & 0.065 & 61.60 & 0.000 & Reject \\
\hline $\begin{array}{l}\text { Preparing Audit } \\
\text { Strategy }\end{array}$ & 9.414 & 0.000 & & & 0.832 & 0.088 & & & Reject \\
\hline $\begin{array}{l}\text { Documenting Audit } \\
\text { Process }\end{array}$ & 5.335 & 0.000 & & & 0.256 & 0.048 & & & Reject \\
\hline
\end{tabular}

Note. * Fixed regression (-0.56) Statistical Significance $\alpha=0.05$.

Table 8 shows that the value of $(\mathrm{R})$ is amounted to $(0.737)$, indicating a high degree of correlation between the requirements of audit planning under the International Auditing Standard no. (300) and Total Quality 
Management. The value of ( $\mathrm{R}$ square) is $(0.54)$, which is a great value that explains the ability of audit planning requirements that effect the total quality management. The value test $(F)$ is $(61.60)$, which is a value statistically significant at the level of significance $(\mathrm{a}=0.05)$, and thus there is a statistically significant effect of the independent variables on total quality management combined.

The First Variable (Prepare for Audit Process Planning (Initial Activities)): The value of $(\beta)$ is $(0.205 \%)$ and the value of $(T)$ is (3.175), which are positive values and statistically significant at the significance level $(\alpha=0.05)$, this indicates the presence of the impact of a variable related to prepare for audit process planning (initial activities) on total quality management, this may be due to the fact that there is awareness among all the auditors about the need to manage their time to the preparing process.

The Second Variable (Preparing Audit Strategy): The value of ( $\beta)$ is $(0.832 \%)$ and the value of $(T)$ is $(9.414)$, which are positive values and statistically significant at the significance level of $(\alpha=0.05)$, this indicates the presence of the impact of a variable related to preparing for audit strategy on total quality management, this indicates that the auditors are following a strategy prepared for the audit process, which means that they use the required time for audit as planned.

The Third Variable (Documenting Audit Process): The value of $(\beta)$ is (0.256\%) and the value of $(T)$ is (5.335), which are positive values and statistically significant at the significance level of $(\alpha=0.05)$, this indicates the presence of a positive impact and a statistically significant variable related to documenting audit process on total quality management. This may be due to the contribution of auditors in following a documentation system in the implementation of quality within business.

\section{Results}

In light of the above study, it showed that there is a statistically significant impact of audit process planning under International Auditing Standard no. (300) on the effectiveness of Total Quality Management, with varying proportions of impact between the independent variables, with the following results in descending order according to the most impact:

Preparing audit strategy variable that affects Total Quality Management, which is the highest impact among other variables.

Then documenting audit process variable that affects Total Quality Management came second.

Finally, the variable of prepare for planning audit process (initial activities) affects Total Quality Management came third.

\section{Recommendations}

The need to increase the interest of Jordanian legal accountants' to prepare for planning audit process and increase their interest in documenting the audit process, which increase the management application of Total Quality Management.

Regular coordination between the internal auditors in companies with Jordanians legal accountants (external auditors) to discuss complex issues and find appropriate solutions, which contribute in applying Total Quality Management.

Conduct studies on Total Quality Management and its impact on the quality of internal or external audit.

\section{References}

Al-Amiri, Al-Mutaz, \& Mohammed, I. (2004). Impact of Electronic Commerce on Audit Planning: An Empirical Study on Audit Firms in Saudi Arabia. Journal of King Abdul Aziz University Economics and Management, 2l(2).

Al-Ghazzawi, M. (2005). Total Quality Management. Amman: Dar Yazouri Al-Elmeyah.

Al-Khalaf, M. (2005). Trinity Discrimination: Improve Quality; Reduce Costs and Increase Productivity. Journal of Public Administration, 37(1), 121-147.

Al-Saadi, I. (2009). The Impact of the Application of Comprehensive Quality Systems on Accounting Systems in the Jordanian Commercial Banks-A Field Study. Gulf University Magazine, 1(4), 41-78.

Al-Samurai, M. (2007). Total Quality Management in Production and Service Sector. Amman: Dar Al-Jaleel for Publishing and Distribution.

Alwan, Q. (2005). Total Quality Management and ISO Requirements. Jordan: The House of Culture for Publishing and Distribution. 
Bazazo, I., \& Al-Amayreh, A. (2010). The Assessment of the Reality of Total Quality Management in Hotels. A field study on a sample of five-star hotels in Jordan. Journal of Human Sciences, 45.

Bennett L. M., \& Kerr, M. A. (2010). A systems approach to the implementation of total quality management. http://dx.doi.org/10.1080/09544129610531

Burk, W. (1997). What Human Resource Practitioners Need to know for The Twenty-First Century. Human Resources Management, 36(8), 71-79.

Fausto, G. (2010). The golden integral quality approach: From management of quality to quality of management. http://dx.doi.org/10.1080/0954412998036

Ghalib, L. S. (2009). A Field Study in the Republic of Yemen. The Auditors' Commitment to the Requirements of Planning of Audit under the International Auditing Standard No. (300).

International Federation of Accountants. (2010). Versions of International Standards for Quality Control, Audit and Review Operations and Other Assurance and Related Services.

Low, K. (2004). The Effects of Industry specialization on audit Risk assessment and audit-Planning Decisions. Accounting Review, 79(1).

Noori, H., \& Radford, R. (1995). Production and Operation Management Total Quality and Responsiveness. U.S.A: Mc Grow-Hill, Inc.

Olimat, N. (2004). Total Quality Management in Educational Institutions and Development Proposals. Dar Al-Shorooq for Publishing and Distribution of Amman.

Sekaran, U. (2003). Research Method for Business: A Skill Building Approach (7th ed.). New York: John Wiley and Sons.

Wilkinson, A. (2007). Total Quality Management and employee Involvement. Human Resource Management Journal, 2(4).

Wright, A., \& Wright, S. (1997). The Effect of Industry Experience on Hypothesis Generation and Audit Planning Decisions. http://dx.doi.org/10.2139/ssrn.42913

Zickien, S. (2009). Implementation of Total Quality Management Systems. Human Resource Management Journal, 17(3), 23-39.

\section{Copyrights}

Copyright for this article is retained by the author(s), with first publication rights granted to the journal.

This is an open-access article distributed under the terms and conditions of the Creative Commons Attribution license (http://creativecommons.org/licenses/by/3.0/). 